\title{
Processing Conditions, Rice Properties, Health and Environment
}

\author{
Poritosh Roy ${ }^{1} *$, Takahiro Orikasa ${ }^{2}$, Hiroshi Okadome ${ }^{1}$, Nobutaka Nakamura ${ }^{1}$ and \\ Takeo Shiina ${ }^{1, *}$
}

1 National Food Research Institute, National Agriculture and Food Research Organization, Kannondai 2-1-12, Tsukuba, Ibaraki 305-8642, Japan; E-Mails: okadome@ affrc.go.jp (H.O.); nboy@affrc.go.jp (N.N.)

2 School of Food, Agriculture and Environmental Sciences, Miyagi University, 2-2-1, Hatatate, Taihaku, Sendai 982-0215, Japan; E-Mail: orikasa@myu.ac.jp

* Authors to whom correspondence should be addressed; E-Mails: poritosh@ affrc.go.jp (P.R.); shiina@affrc.go.jp (T.S.); Tel.: +81-29-838-8027; Fax: +81-29-838-7996.

Received: 17 March 2011; in revised form: 25 May 2011 / Accepted: 27 May 2011 /

Published: 3 June 2011

\begin{abstract}
Rice is the staple food for nearly two-thirds of the World's population. The food components and environmental load of rice depends on the rice form that results from different processing conditions. Brown rice $(\mathrm{BR})$, germinated brown rice (GBR) and partially-milled rice (PMR) contains more health beneficial food components compared to well milled rice (WMR). Although the arsenic concentration in cooked rice depends on the cooking methods, parboiled rice (PBR) seems to be relatively prone to arsenic contamination compared to untreated rice, if contaminated water is used for parboiling and cooking. A change in consumption patterns from PBR to untreated rice (non-parboiled), and WMR to PMR or BR may conserve about 43-54 million tons of rice and reduce the risk from arsenic contamination in arsenic prone areas. This study also reveals that a change in rice consumption patterns not only supplies more food components, but also reduces environmental loads. A switch in production and consumption patterns would improve food security where food grains are scarce, and provide more health beneficial food components, may prevent some diseases and ease the burden on the Earth. However, motivation and awareness of the environment and health, and even a nominal incentive may require for a method switching which may help in building a sustainable society.
\end{abstract}


Keywords: rice processing; rice properties; $\mathrm{CO}_{2}$ emission; health; environment

\section{Introduction}

Rice (Oryza sativa L.) is the staple food for nearly two-thirds of the World's population [1]. It has been reported that as much as $75 \%$ of the daily calorie intake of the people in some Asian countries is derived from rice [2]. It is reported that the World's stocks of stored rice grain have been falling relative to each year's use, because the consumption has surpassing the production [3]. The deficiency of food production not only increases the price of food, but also increases the malnourished population in the World, which might result in different social and economic unrest. Researchers have also predicted that global warming will make rice crops less productive [4-7] and it could threaten to erase the hard-won productivity gains that have so far largely kept the rice harvests in step with population growth. Rice processing is a combination of several operations to convert paddy rice into well milled silky-white rice, which has superior cooking quality attributes [8]. The majority of consumers prefer well milled rice (WMR) with little or no bran remaining on the endosperm. It has also been reported that consumer preferences vary from region to region. For instance, the Japanese like well milled sticky rice [9], but Americans prefer semi-milled long grain or even brown rice (BR), whereas people in the Indian sub-continent prefer well milled parboiled rice [10].

Rice properties are known to be dependent on the variety of rice, methods of cultivation, processing and cooking conditions. Although the parboiling treatment helps in retaining some of the nutrients, reduce breakage loss during milling and increases head rice recovery (whole rice kernels after milling), a considerable amount of energy and labor is consumed. It has also been reported that the nutritional value and head rice recovery are reduced with the higher degree of milling (DOM). Usually, 10\% by weight of brown rice is removed (outer layer) during milling, with the lower values occurring in countries where the DOM is regulated [11]. Rahaman et al. [12] reported that milling should be restricted to 7 to $8 \%$ for maximum recovery, which is the common practice in most developing countries, including Bangladesh. In India, it is restricted to $4 \%$ by weight of BR [13]. The proteins, fats, vitamins, and minerals are concentrated in the germ and outer layer of the starchy endosperm $[11,14]$ and these are removed by milling operations. The growing health consciousness has led consumers to start consumption of rice milled to lower degrees (partially-milled rice: PMR) or even BR in some countries. In addition various value-added rice products [germinated brown rice (GBR), rice bread (RB) etc.] have also been developed. Rice properties and the environmental impacts of rice are known to be dependent on the variety of rice, methods of cultivation and processing conditions, and consumption patterns. Hence, it is the authors' intention to discuss rice processing, the physicochemical properties of rice, and their impact on food security, human health and the environment. 


\section{Rice Processing}

\subsection{Parboiling}

Parboiling is an ancient method of rice processing, widely used in the developing countries like Bangladesh, India, Sri Lanka, and in some rice exporting countries. Parboiled rice (PBR) has been produced by both traditional and modern methods. Various parboiling devices and techniques have been developed [12,15-32]. Modern methods are energy and capital intensive, and are not suitable for small-scale operation at the village level $[25,33]$. The local parboiling devices range from pottery to boiler, use direct or indirect heating and single or double steaming, which consume all different amounts of energy [34,35]. Agri-residues are the main sources of energy for local parboiling, especially the residues of rice processing industries. However, sun drying is a common practice in local parboiling processes. A nearby pond, river, lake or tube-well is the source of the water for parboiling. Figure 1 shows an overview of local parboiling processes.

Figure 1. An overview of local parboiling processes [35].

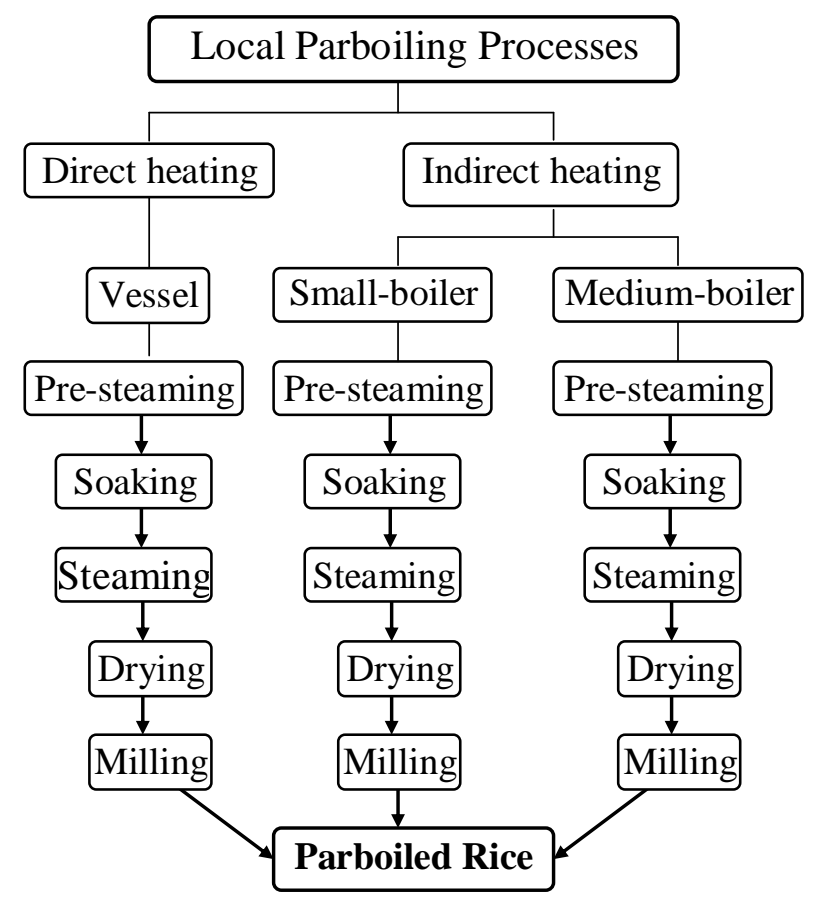

Parboiling treatment induces various physicochemical changes in paddy rice which play an important role in the subsequent storage, milling, cooking and eating qualities [36-46]. Although PBR is known to have a number of advantages, it requires more energy, water and time for processing and cooking [35,47-51] than untreated rice. The parboiling treatment gelatinizes the rice starch, improves the hardness of the rice upon drying, minimizes the breakage losses and thus increases the milling yield [42,45,52-54]. Over-parboiling results in over-opening of the husk components followed by bulging out of the endosperm which initiates surface scouring during milling and the resultant ground particles being lost into the husk and bran. However, incomplete or non-uniform parboiling produces white-bellied rice, which breaks easily during milling, and reduces the head rice yield [22,55]. The parboiled rice produced in the boiler processes is considered to be more suitable and better because it 
has greater customer acceptance and market value, but it requires a greater initial investment [35]. The quality of PBR depends on the paddy rice, intensity of parboiling, drying condition and moisture content after drying, DOM and the milling devices [34,40,44,54,56-58].

\subsection{Dehusking and Milling}

Dehusking and milling process removes the outer part of paddy rice (husk and bran) to make it edible. There are three main types of husking machine, including stone dehullers, rubber rolls and impeller type huskers [59]. Stone de-hullers are still common in tropical Asia, where BR is immediately milled with either an abrasive or a friction mill. It has been reported that different types of liner significantly affect the husking performance [60]. It has also been reported that the Engleberg-type or steel hullers are no longer acceptable in the commercial rice milling sector, as they lead to low milling recovery and high grain breakage [61]. Abrasive or friction type milling machines are used to remove the bran. It has been reported that the abrasive mill can over-mill readily. In the Engelberg or huller type mill, dehusking and milling are performed in one step with greater grain breakage. Using a dehusker before milling improves both the milling and head rice yields. During parboiling treatment the husk splits and loosen, which makes dehusking easier [24,47]. The energy consumption during the dehusking process is also caused by the severity of the steaming treatment and it tends to have decreased with the increase of steaming time [34].

The DOM is a quantification of the amount of bran that has been removed from kernels during the milling process. The DOM is influenced by the grain hardness, size and shape, depth of surface ridges, bran thickness and milling efficiency [62]. Harder rice requires greater energy to obtain the same DOM [34,62]. The energy consumption during milling is also depends on the grain thickness, hardness, shape and variety, and DOM [34,62-65]. Lower surface hardness facilitates breakage during milling, resulting in lower milled rice recovery and quality [66] in the case of long grains compared to that of short grains. Mass loss and breakage are affected by cultivar, kernel shape, and thickness of the aleurone layer $[67,68]$. The flow ability of short grains is higher than that of long grains through the milling chamber of friction type milling machine which results in lower degree of breakage during milling [12], and leads to the production of greater amounts of head rice. Roy et al. [51] reported that in the case of the milled rice option, PBR contains $3 \%$ broken grains and untreated rice contains $13 \%$ broken grains, and would be acceptable to the local consumers. The overall energy consumption during dehusking and milling is reported to be greater in the case of PBR compared to the untreated rice [34]. The rice properties desired by consumers include whiteness, translucency, low percentage of damaged or broken grains and low foreign matter. The amount of bran in rice kernels varies with variety, environmental conditions and agronomic practices [66,69]. The bran is reported to be darker than the polish [11]. In the case of untreated rice, head rice yields decrease and lightness increases with an increase in DOM $[58,65,70]$. The BR of Japonica variety has greater color intensity than that of Indica variety $[65,69]$. For a certain DOM the difference in milling yield between short and long grains is reported to be insignificant (Figure 2). 
Figure 2. Effect of degree of milling on milling and head rice yield [65].

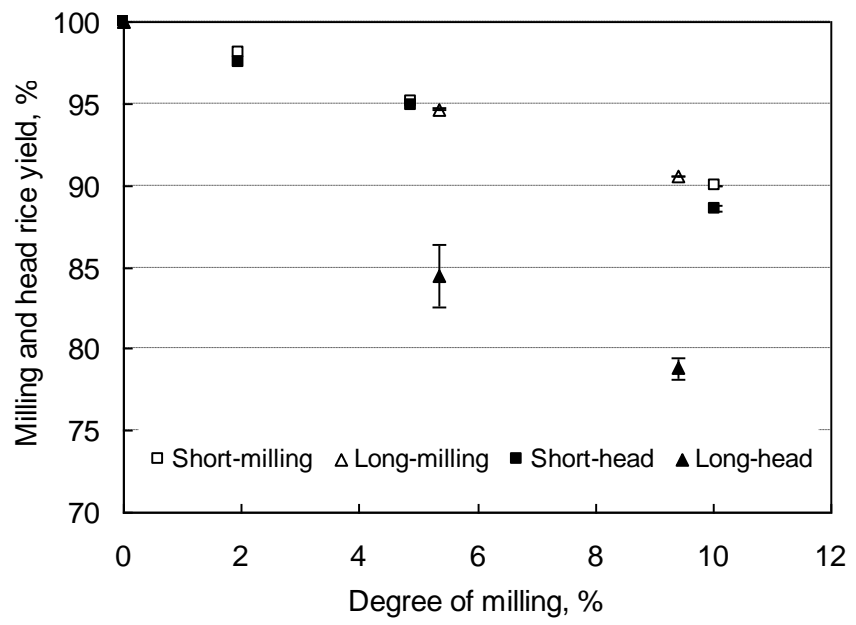

\subsection{Germinated Brown Rice}

Brown rice kernels soak in warm water $\left(30-40{ }^{\circ} \mathrm{C}\right)$ until they just begin to bud (the exact time depends on the water temperature), giving the product which is known as germinated brown rice (GBR). The potential health benefits and superior quality of GBR have attracted public attention and it has become a popular healthy food, and different local governments (prefectures) in Japan are promoting the consumption of GBR. As a result of its popularity, modern rice cookers have also been developed to facilitate the production of GBR at households with various time spans $(6-15 \mathrm{~h})$. In this process, washed BR is used to put in the rice cooker vessel with adequate amounts of water. Roy et al. [71] used $2.9 \mathrm{~L}$ water for $750 \mathrm{~g}$ of rice in the germination process. The water temperature in the rice cooker during the germination process is reported to be about $31^{\circ} \mathrm{C}$ [72]. The germinated rice is washed several time to avoid off odors, hence more water is required compared to other forms of rice [72].

The GBR contains much more fiber, the essential amino acid lysine, and $\gamma$-aminobutyric acid (GABA) than conventional BR. GBR contains more nutrients compared to the milled rice i.e., 10 times the amount of GABA, and about four times the dietary fiber, vitamin E, niacin and lysine, and about three times the vitamins $B_{1}, B_{2}$ and magnesium [73]. Saikusa et al. [74] reported that $\gamma$-aminobutyric acid (GABA) increased dramatically if BR is soaked in water at $40{ }^{\circ} \mathrm{C}$ for $8-24 \mathrm{~h}$. The phenolic compounds are also reported to be more abundant in BR and GBR [75]. These nutrients accelerate the metabolism of the brain helping prevent major diseases such as gastrointestinal cancers, heart disease, high blood pressure, diabetes and beriberi, constipation, and Alzheimer's disease [73,76-79]. Jeon et al. [80] concluded that GBR may be effective for suppressing liver damage. GBR also enhances maternal mental health and immunity during lactation [81]. Okada et al. [82] reported that intake of GABA for eight consecutive weeks reduced blood pressure and improved sleeping, and autonomic disorders observed during the menopausal or presenile period.

\subsection{Hydration and Cooking}

Milled and BR exhibit different rates of moisture absorption $[65,83]$, with milled rice initially absorbing water at a faster rate than BR because the milling treatment removes the outer protective layers 
of rice caryopsis, so the endosperm of milled rice becomes relatively prone to water absorption [84]. On the other hand, the wax content in the BR seed coat and on the pericarp reduces water absorption [85]. Roy et al. [65] noted that the difference in the rate of water absorption is insignificant among the rices milled to different DOM, which supports the earlier findings that removing $1 \%$ of the outer BR kernel increases the water absorption relative to that of highly milled rice [86]. The final moisture distribution in $\mathrm{BR}$ is reported to be more homogeneous than in milled rice [87]. It is also reported that approximately $24 \%$ moisture evenly distributed throughout the grain is enough to bring out its gelatinization after normal atmospheric steaming [19,26,88] which indicates that $1 \mathrm{~h}$ of soaking might be enough to facilitate the cooking process of rice [65]. The gelatinized starch hydrates more compared to raw starch [89]. The PBR absorbs water at a faster rate and to a higher extent at low (room) temperature and it is proportional to the severity of heat treatment $[16,49,90,91]$. If water absorption during this process is insufficient, the starch in the central part of the grain does not fully gelatinize and swell, resulting in cooked grains with a hard texture [92].

The presoaking treatment improves the moisture content (MC) of rice, appears to cause quick heat transfer during cooking and thereby reduces the cooking time $[49,91,93]$. The functionality and sensory properties of rice are also reported to be affected by the DOM, processing conditions and the variety of rice. It is also reported that larger and thicker grains require longer cooking times [94,95]. Milling reduces the kernel size and gelatinization temperature (GT) to about 20\% DOM [96], possibly leading to decreases in preset cooking times for various forms of rice. The thermal properties of rice are reported to be dependent on the variety and processing conditions which affect its cooking properties [96-101]. Physicochemical properties, such as MC, adhesion and hardness, cooking time, energy consumption are all induced by the processing conditions which affect the eating quality of rice. The stickiness of PBR decreases due to parboiling treatment and depends on the severity of treatment $[49,102-104]$. The hardness of cooked rice is reported to depend on the MC of cooked parboiled and untreated rice $[49,65,104,105]$. Roy et al. [106] noted that the hardness and adhesion of cooked rice were dependent not only on the MC but also on the forms and variety of rice. The MC in cooked rice for acceptable soft texture (66-69\%: [49]) or optimally cooked rice (about 75\%: [94]) varies widely. Also, the PBR requires a greater water-rice ratio during cooking than that of untreated rice. Rice with low amylose content is generally soft when cooked, whereas rice with high amylose content has higher grain hardness [107]. High-amylose rice has more very long chains than low-amylose rice [108,109]. The more long chains, the firmer the rice is when cooked and vice-versa [110]. Rice with high water binding capacity normally yields soft texture cooked rice [95]. At the same level of MC, cooked PBR is reported to be harder than the cooked untreated rice $[91,102]$. Cooked PBR retains better shape, reduced stickiness, and lesser solids losses into the cooking gruel, if cooked in excess water [24,111]. The loss depends on the severity of parboiling [94,104,112].

Rice contamination if contaminated water is used for cultivation, processing and cooking has been reported, [113-126]. Highly significant genetic differences in arsenic accumulation during rice cultivation were detected in the arsenic contaminated area in Bangladesh. The contamination was higher for the traditional variety (Bangladeshi landraces) compared to that of improved BRRI cultivars. The rate of contamination was also dependent on the concentration of arsenic in water used for irrigation [126]. The boro (grown in Summer: November-June) had greater total arsenic compared with aus (prekharif: April-September) and aman rice (irrigated by rain water, kharif: June-December) 
which was related to the use of a higher volume of arsenic polluted ground water for irrigation [121]. The arsenic contamination also depends on the processing conditions of rice. Higher contamination was noted for the parboiled rice compared to that of untreated rice, when contaminated water was used for parboiling treatment. Final arsenic concentrations were reported to be 332 and $290 \mu \mathrm{g} / \mathrm{kg}$ in raw parboiled and untreated rice, respectively [122].

Arsenic retention in cooked rice is dependent on the type and variety of rice, cooking method, and arsenic concentration in the cooking water, if arsenic contaminated water is used for cooking [115,120-124,127,128]. Arsenic retention in rice varied from $45-107 \%$ of the arsenic in cooking water $[113,116,118,124]$. On the other hand, Devasa et al. [120] noted that all the arsenic present in cooking water may be retained during boiling of rice, increasing the contents of this metalloid to significant levels from a toxicological viewpoint. Bae et al. [113] reported that the arsenic retention in cooked rice is also dependent on the water absorption of rice. Roychowdhury et al. [117] confirmed that total arsenic content increases where the water used for cooking had high arsenic contents. The arsenic retention in cooked rice is reported to be lower in excess water cooking method compared to that of optimum water [121,128]. Sengupta et al. [116] described that when the rice (four different varieties) is cooked in an excess of water and the remaining water is then discarded the retention of arsenic is less $(43 \%)$ than that observed in optimum water cooking (no cooking gruel) preparations (72-99\%).

In the excess water cooking method arsenic concentration in cooked rice (BRRI 28, parboiled) and in gruel were $0.40 \pm 0.03$ and $1.35 \pm 0.04 \mathrm{mg} / \mathrm{kg}$, respectively. In the case of non-parboiled (untreated) rice, arsenic concentration in cooked rice and in gruel was reported to be $0.39 \pm 0.04$ and $1.62 \pm 0.07 \mathrm{mg} / \mathrm{kg}$, respectively. Arsenic concentrations in parboiled and untreated rice were $0.89 \pm 0.07$ and $0.75 \pm 0.04 \mathrm{mg} / \mathrm{kg}$, respectively, if cooked in optimum water (no cooking gruel). However, no significant difference was reported between cooked parboiled and untreated BRRI hybrid rice with optimum water cooking methods [115]. It seems that non-contaminated water was used for parboiling treatments in that study, hence no difference in arsenic content between raw parboiled and untreated rice was reported. Rinse washing and high volume of cooking water is reported to be effective, if distilled water is used. The high volume excess water cooking method removed $35-45 \%$ arsenic compared to that of uncooked rice [128]. Rinse washing was effective for removing about $10 \%$ of the total and inorganic arsenic from basmati rice, but less effective for other types of rice. Hence, it seems that PBR becomes relatively prone to arsenic contamination compared to that of untreated rice, if contaminated water is used for parboiling and cooking. Arsenic contamination could be avoided or controlled, if contaminated water is not used in rice cultivation, processing and cooking.

\section{Food Components, Health and Environment}

Kernels that have been milled to a different degree reportedly have varying functional and sensory properties $[129,130]$. Protein concentration is highest on the surface and gradually decreases toward the center of the kernel [58,131], however, starch concentration increases from the surface to the core of the milled rice. The germ and bran contain high level of minerals, proteins and vitamins. The removal of the germ and bran from the BR produces milled rice which contains less food nutrients compared to that of BR (uncooked). Water soluble nutrients disperse into the endosperm but fat moves out during parboiling treatment, hence parboiled milled rice contains more water soluble nutrients and 
lesser fat for a certain DOM [132,133]. All the thiamine is removed from the untreated BR but only half from parboiled, if a $10 \%$ outer portion is removed [134]. On the contrary, total thiamine and nicotinic acid content in BR are reported to be reduced after parboiling [134,135]. The protein content of brown or milled rice was noted to be unaffected by parboiling [41]. The solubility of protein decreases after parboiling [41,136]. The riboflavin content also remains unaffected [137,138]. The energy and protein contents were estimated to be increased, and the lipid and dietary fibers decreased with the increase of DOM. The higher MC yields greater amount of cooked rice, might offset the difference in the energy and the protein contents $[65,71,106]$. Table 1 shows food components in different forms of rice. Energy content in Japonica rice is greater compared to the Indica rice, which might be because of lower MC, which indicates that for a certain amount of energy intake, greater amount of cooked Indica rice need to be consumed compared to that of Japonica.

Table 1. Food components in different forms of cooked rice (hardness of cooked rice, 10 N) [72].

\begin{tabular}{lcccccc}
\hline \multirow{2}{*}{$\begin{array}{c}\text { Variety/ forms of } \\
\text { Rice }\end{array}$} & DOM, & MC, $\%$ & \multicolumn{4}{c}{ Food components and energy content per 100 grams cooked rice } \\
\cline { 5 - 7 } & $\boldsymbol{\%}$ & $\mathbf{w . b .})$ & Carbohydrate, $\mathbf{g}$ & Dietary fiber, g & Protein, $\mathbf{g}$ & Lipid, $\mathbf{g}$ \\
\hline \multirow{3}{*}{ Koshihikari } & 0.0 & 69.1 & 26.1 & 1.3 & 2.1 & 1.0 \\
& 2.0 & 66.3 & 29.3 & 1.1 & 2.2 & 0.8 \\
& 5.0 & 64.8 & 31.5 & 0.7 & 2.3 & 0.6 \\
& 10.0 & 61.5 & 35.6 & 0.5 & 2.5 & 0.4 \\
\hline \multirow{2}{*}{ IR28 } & 0.0 & 72.5 & 22.0 & 1.3 & 2.8 & 0.9 \\
& 5.4 & 72.0 & 24.0 & 0.7 & 2.7 & 0.3 \\
\hline Germinated brown rice & - & 63.7 & 30.6 & 0.7 & 2.8 & 0.2 \\
Parboiled (Basmati) & - & 70.1 & 26.4 & 1.7 & 2.5 & 0.9 \\
\hline
\end{tabular}

Agriculture provides the nutrients essential for human life. Insufficient output of even one essential nutrient over a long time will create several social and human health problems [139]. McCarrison and Norris [140] concluded that beriberi is associated with the consumption of untreated rice, but not with the PBR. It is also noted that incidence of beriberi drops dramatically when an untreated rice diet is changed to PBR [141]. The presence of the amylose-lipid complex II may contribute to the low postprandial glucose increments, since these complexes have melting temperatures above $100{ }^{\circ} \mathrm{C}$ and, therefore, are not melted during the cooking of neither the untreated or the PBR samples. Most rice used for parboiling has intermediate (20-25\%) or high (>25\%) amylose content [142]. It has noted that high amylose content lowers the starch digestion rate, measured as the glycaemic or insulinaemic response to rice [143-146]. It is also noted that parboiling treatment lowers the glycaemic response to rice and it depends on the severity (intensity) of parboiling [147,148]. In contrast, no difference has also been reported $[145,146]$. It seems that not only parboiling but also the variety and forms of rice play an important role in the glycaemic response of rice. Growing health concerns have led humans to diversify their diet and helps to avoid some diet related diseases. The enrichment and fortification of cereals and other foods has had a significant impact on the prevention of disease [149] and the development of functional foods may also play a key role in controlling/avoiding diet related diseases.

The environmental impacts of rice depend on the location of cultivation, variety, processing and forms of rice $[50,51,71,150,151]$. It is reported that half of the World's households cook daily with 
biomass energy. Domestic cooking-stoves - either traditional or improved - used for cooking in rural areas cause incomplete combustion of biomass and emit gaseous substances and suspended particulates which are responsible for many health problems [152,153]. Women who do the cooking are exposed to the domestic smoke and also the children, particularly infants and young children, who spend most of their time around their mother. PBR requires longer cooking time than that of untreated rice $[49,94]$. It seems that longer cooking time not only consumes greater energy but also forces those (who do the cooking) to suffer longer exposure to domestic smoke than that of untreated rice which may have greater health risks in the rural area of the developing countries. The untreated process is noted to be both the environmentally sustainable and cost effective process compared to the PBR, if milled rice is consumed instead of head rice [51]. Figure 3 represents the life cycle emission of different forms of rice [Koshihikari \& Basmati (parboiled)].

Figure 3. Life cycle $\mathrm{CO}_{2}$ emission of different forms of rice.

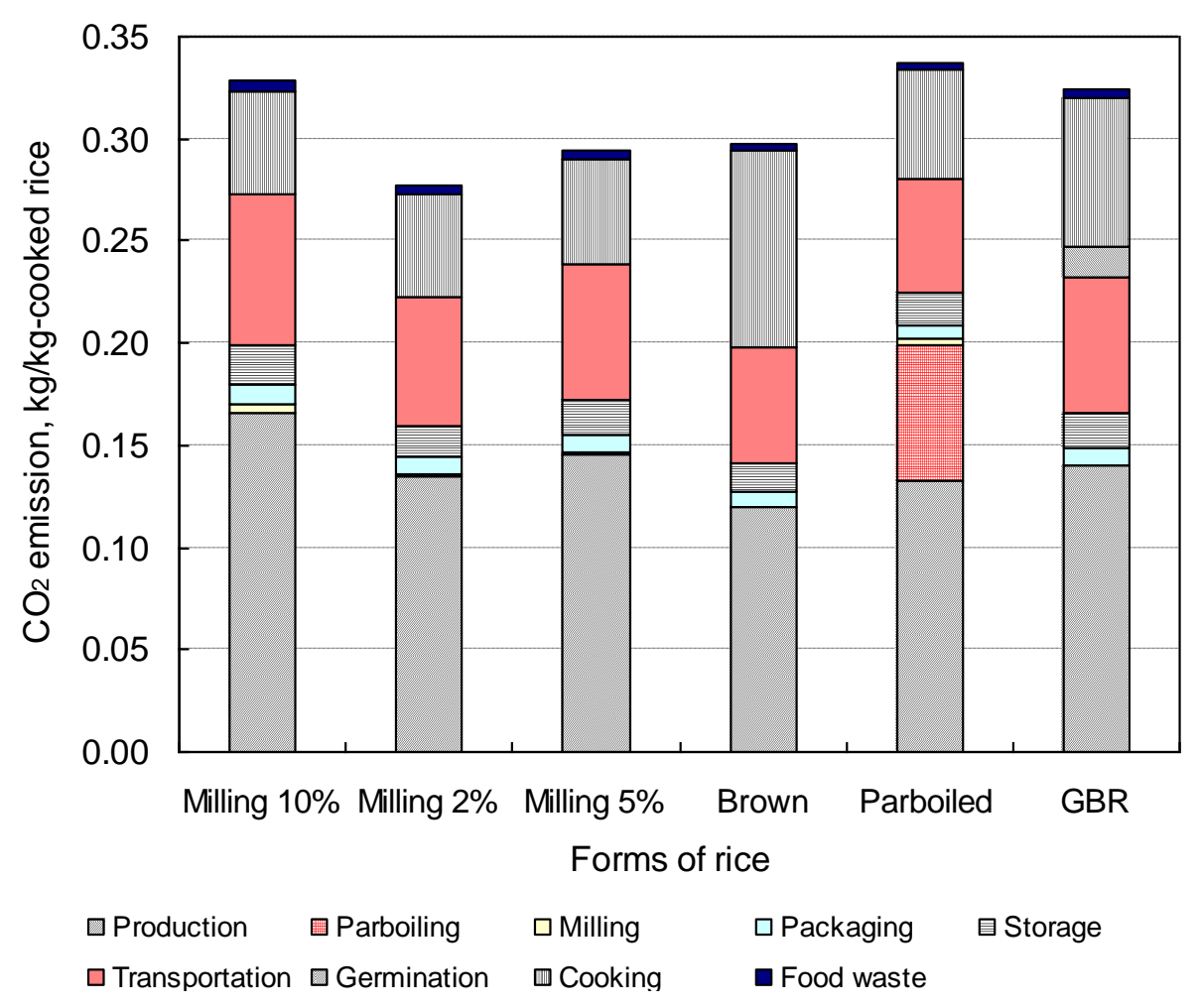

The life cycle emissions were found to be the highest for PBR, followed by GBR, and the lowest was for PMR (milling, 2\%). Emissions were greater for BR than those of WMR and PMR, even though no milling is required because more energy is consumed during cooking compared to the others. The environmental load of PMR rice was found to be slightly lower than that of WMR because of the difference in head rice yield, which leads to lower production stage emissions. It is also noted that a change in rice consumption patterns would reduce $2-16 \%$ of $\mathrm{CO}_{2}$ emissions from the life cycle of rice $[71,72]$.

PBR also requires more water than PMR, BR and untreated rice because a considerable amount of water is used during soaking and steaming. GBR also requires more water than PBR because of the huge amount of water required during germination and washing the GBR (to control odor) before it is cooked or packed [106]. Although the effluents discharged from local rice mills do not contain any 
toxic compounds or pathogenic bacteria, repeatedly discharging them into the open may become a public health hazard, as the stagnant water not only encourages a variety of organisms but also emits off-odors in and around the local area. Relatively higher populations of total aerobic bacteria, staphylococci, lactic acid bacteria and yeast were reported in soaked water from the cold soaking method than the others. Modern rice mills are adopting hot soaking and where there is a continuous discharge of effluents, with a high chemical oxygen demand (COD), phenols and sugars, into a localized area there may be environmental concerns [154]. Table 2 shows the biochemical characteristics of soaked water from different parboiling methods. Growth of the parboiling sector or GBR sector may lead to water shortages and contamination. Washing is a common practice in the cooking process of rice. Biological oxygen demand (BOD) and COD in washed water known to be higher for milled rice compared to that of BR or PBR. Total BOD and COD in washed water produced by washing of $166 \mathrm{~g}$ regular rice (WMR) are reported to be 2,685 and 1,207 $\mathrm{mg}$, respectively (http://www.musenmai.com/nichido.html).

Table 2. Biochemical characteristics of soaked water of different parboiling methods [154].

\begin{tabular}{|c|c|c|c|c|c|}
\hline \multirow{2}{*}{$\begin{array}{l}\text { Source of } \\
\text { soaking water }\end{array}$} & \multirow{2}{*}{$\begin{array}{c}\text { Soaking } \\
\text { time, } h\end{array}$} & \multicolumn{4}{|c|}{ Components, mg/L } \\
\hline & & Total sugar & Amino nitrogen & Total phenol & BOD \\
\hline \multirow[t]{2}{*}{ Household } & 0 & 4 & 0 & 3 & 140 \\
\hline & 12 & 10 & 17 & 4 & 206 \\
\hline \multirow[t]{2}{*}{ Cold-soaking } & 0 & 4 & 0 & 3 & 140 \\
\hline & 72 & 47 & 61 & 10 & 1039 \\
\hline \multirow[t]{2}{*}{ Double-steaming } & 0 & 22 & 9 & 19 & 117 \\
\hline & 24 & 63 & 78 & 48 & 293 \\
\hline \multirow[t]{2}{*}{ Hot-soaking } & 0 & 34 & 0 & 4 & 129 \\
\hline & 4 & 641 & 104 & 62 & 30 \\
\hline Pressure-parboiling wash water & - & 1 & 7 & 20 & 57 \\
\hline
\end{tabular}

It seems that the PMR may not only reduce the environmental load but also improves the head rice yield compared to that of WMR. Although GBRs consume greater amounts of water, the BR, PMR (DOM 2\%) and GBR option would improve food security in the regions where food is scarce, especially in developing countries. Moreover, PMR, BR and GBR provide various health benefits beyond their nutritional values. Considering their environmental load, it would be wiser to consume PMR than other forms. However, the taste of rice and its acceptability need to be considered to adopt lower DOM.

\section{Discussion}

The combination of population growth and economic development with the decreasing per capita land area, puts a great stress on arable land, water, energy and biological resources. The necessary expansion of global food production is becoming increasingly difficult to achieve. Water scarcity together with soil erosion, land degradation and climate change are the main threats to future increase in productivity. It is also noted that the climate change will make rice crops less productive [4-7] and it could threaten to erase the hard won productivity gains that have so far managed to keep rice harvests in step with population growth. As rice consumption surpasses production, the World's stocks of stored 
rice grain have been falling relative to each year's use [3]. The deficiency of food production not only increases the food prices, but also will increase the numbers of malnourished population in the World which in turn might cause social and economic unrest. It is reported that 864 million people were undernourished worldwide in 2002-2004 [155].

The standard of rice and consumption preferences varies from country to country and region to region. Although the economic value of rice depends on the percent of whole milled grain production, the production cost, rice yield and food components in rice depend on the forms of rice [51,71]. The World paddy production was reported to be 685 million tons in 2008 [156]. This would produce about 541, 530, 514, 498 and 487 million tons of rice, if DOM is restricted to 0, 2, 5, 8 and 10\%, respectively [72]. A change in consumption patterns from PBR to untreated rice, WMR to BR which contain more health beneficial food components may conserve about 43-54 million tons of rice and reduce the risk of rice contamination and prevent some diseases. It would be very helpful in the countries or region, where food grains are scarce and would help abate malnourishment. Most of the milling facilities in the local areas produce a byproduct as a mixture of the husk, bran and broken grains and used as poultry or animal feed, or as a solid biomass fuel in the rural area of the developing countries, have to be considered for any such change. However, considering the scarcity of food grains, and energy consumption and environmental pollution, it would be wise to consume untreated PMR, if consumers are satisfied with its taste. Adoption of PMR not only ease the burden of the Earth but also provide more health beneficial food components for humans' well being. Moreover, motivation and awareness of the environment and health, and even a nominal incentive may be require for such a method switch.

\section{Conclusions}

This study reveals that the physicochemical and thermal properties and environmental load of rice depend on the production and processing conditions. BR, GBR and PMR contain more health beneficial food components than WMR, which help avoid different diseases. A change in consumption patterns from PBR to untreated rice, and WMR to PMR may conserve a considerable amount of grains. A switch in production and consumption patterns would improve food security where food grains are scarce, and also provides more health beneficial food components and ease the environmental burden of the Earth. Although the arsenic concentration in cooked rice depends on the cooking methods, parboiled rice (PBR) seems to be relatively prone to arsenic contamination compared to that of untreated rice, if contaminated water is used for parboiling and cooking. However, consumer preference and taste of rice have to be considered for any method switching.

\section{References}

1. Wynn, T. Rice Farming: How the Economic Crisis Affects the Rice Industry. Presented at the Rice Producers Forum, USRPA, Houston, TX, USA, 20 August 2008; Available online: http://www.ricefarming.com/home/2009_JanProducersForum.html (accessed on 7 May 2009). 
2. FAO (Food and Agricultural Organization). Rice in the World. In Report of the Fifth External Programme and Management Review of the International Plant Genetic Resources Institute (IPGRI); FAO: Rome, Italy, 2001; Available online: http://www.fao.org/wairdocs/tac/x5801e/ x5801e08.htm (accessed on 11 December 2009).

3. Roy, P.; Shiina, T. Global Environment, Biofuel: Sustainable Food Production and Distribution. In Global Environmental Policies: Impact, Management and Effects; Riccardo, C., Monte, G., Eds.; Nova Science Publishers: New York, NY, USA, 2010; pp. 29-58.

4. Satake, T.; Yoshida, S. High temperature induced sterility in Indica rice at flowering. Jpn. J. Crop. Sci. 1978, 47, 6-17.

5. Ziska, L.; Manalo, P. Increasing night temperature can reduce seed set and potential yield of tropical rice. Aust. J. Plant Physiol. 1996, 23, 791-794.

6. Peng, S.; Huang, J.; Sheehy, J.E.; Laza, R.C.; Visperas, R.M.; Zhong, X.; Centeno, G.S.; Khush G.S.; Cassman, K.G. Rice yields decline with higher night temperature from global warming. Proc. Natl. Acad. Sci. USA 2004, 101, 9971-9975.

7. Sheehy, J.E.; Elmido, A.; Centeno, G.; Pablico, P. Searching for new plants for climate change. J. Agric. Meteorol. 2005, 60, 463-468.

8. Roberts, L.R. Composition and taste evaluation of rice milled to different degrees. J. Food Sci. 1979, 44, 127-129.

9. Deshpande, S.S.; Bhattacharya, K.R. The texture of cooked rice. J. Texture Stud. 1982, 13, 31-42.

10. Lyon, B.G.; Champagne, E.T.; Vinyard, B.T.; Windham, W.R.; Barton, F.E.II.; Webb, B.D.; McClung, A.N.; Moldenhauer, K.A.; Linscombe, S.; McKenzie, K.S.; et al. Effects of degree of milling, drying condition and moisture content on sensory texture of cooked rice. Cereal Chem. 1999, 76, 56-62.

11. Juliano, B.O.; Bechtel, D.B. The Rice Grain and Its Gross Composition. In Rice Chemistry and Technology, 2nd ed.; Juliano, B.O., Ed.; American Association of Cereal Chemists: Eagan, MN, USA, 1985; pp. 17-57.

12. Rahaman, M.A.; Miah, M.A.K.; Ahmed, A. Status of rice processing technology in Bangladesh. Agric. Mech. Asia Afr. Latin Am. 1996, 27, 46-50.

13. Tani, T. Milling Quality and Eating Quality of Rice. In Group Training Course in Postharvest Rice Processing; Japan Rice Millers Association: Tokyo, Japan, 1983.

14. Itani, T.; Tamaki, M.; Arai, E.; Horino, T. Distribution of amylase, nitrogen, and minerals in rice kernels with various characters. J. Agric. Food Chem. 2002, 50, 5326-5332.

15. Central Food Technological Research Institute (CFTRI). Parboiling of Paddy; Project Circular 7 (revised), Central Food Technological Research Institute: Mysore, India, 1969.

16. Swamy, Y.M.I.; Ali, S.Z.; Bhattacharya, K.R. Hydration of raw and parboiled rice and paddy at room temperature. J. Food Sci. Technol. 1971, 8, 20-22.

17. Gariboldi, F. Parboiled rice. In Rice chemistry and technology, 1st ed.; Houston, D.F., Ed.; American Association of Cereal Chemists: Eagan, MN, USA, 1972; pp. 358-380.

18. Tiwary, T.; Ojha, T.P. Performance of boilerless parboiling system. J. Agric. Mech. Asia Afr. Latin Am. 1981, Winter, 60-62.

19. Ali, S.Z.; Bhattacharya, K.R. Studies on pressure parboiling of rice. J. Food Sci. Technol. 1982, 19, 236-242. 
20. Adhikarinayake, T.B.; Swarnasiri, D.P.C. An mproved home level parboiling technique. Sri. Lankan J. Post Harvest Technol. 1988, 1, 19-22.

21. Obobi, A.A.; Anazodo, U.G.N. Development of a rice parboiling machine. J. Agric. Mech. Asia, Afr. Latin Am. 1988, 18, 53-54.

22. Sarker, N.N.; Farouk, S.M. Some factors causing milling loss in Bangladesh. J. Agric. Mech. Asia, Afr. Latin Am. 1989, 20, 49-56.

23. Shukla, B.D.; Khan, A.U. Microwave energy: A new concept in paddy parboiling. J. Agric. Mech. Asia Afr. Latin Am. 1989, 20, 47-52.

24. Bhattacharya, K.R. Parboiling of rice. In Rice Chemistry and Technology, 2nd ed.; Juliano, B.O., Ed.; American Association of Cereal Chemists, Inc.: St. Paul, MN, USA, 1985; pp. 289-348.

25. Bhattacharya, K.R. Improved Parboiling Technologies for Better Product Quality; Indian Food Industry: Mysore, India, 1990; pp. 23-26.

26. Pillaiyar, P.; Singaravadivel, K.; Desikachar, H.S.R.; Subramaniyan, V. Low moisture parboiling of paddy. J. Food Sci. Technol. India 1993, 30, 97-99.

27. Pillaiyar, P.; Singravadivel, K.; Desikachar, H.S.R. Quality changes in HTST processing of rice parboiling. J. Food Sci. Agric. 1994, 65, 229-231.

28. Haque, A.K.M.A.; Choudhury, N.H.; Quasem, M.A.; Arboleda, J.R. Rice post-harvest practices and loss estimates in Bangladesh-Part III: Parboiling to milling. J. Agric. Mech. Asia, Afr. Latin Am. 1997, 28, 51-55.

29. Kimura, T. Temperature Deviation Patterns in a Batch Parboiling Tank. In Proceedings of the International Agricultural Engineering Conference, Pune, India, 9-12 December 1996.

30. Rao, P.V.K.J.; Bal, S.; Chakraverty, A. Use of Pneumatic pressure in parboiling paddy. J. Agric. Mech. Asia, Afr. Latin Am. 1997, 28, 69-71.

31. Pillaiyar, P.; Singravadivel, K.; Desikachar, H.S.R. A rapid test to determine hard pressure parboiled rice from other parboiled rices. Food Sci. Technol. 1997, 34, 532-533.

32. Kar, N.; Jain, R.K.; Srivastav, P.P. Parboiling of dehusked rice. J. Food Eng. 1999, 39, 17-22.

33. Ali, N.; Ojha, T.P. Parboiling rice. In Post Harvest Technology; Araullo, E.V., De Padua, D.B., Graham, M., Eds.; IDRC: Ottawa, Canada, 1976; pp. 163-204.

34. Roy, P. Improvement of Energy Requirement in Traditional Parboiling Process. PhD Thesis, University of Tsukuba, Ibaraki, Japan, 2003.

35. Roy, P.; Shimizu, N.; Shiina, T.; Kimura, T. Energy consumption and cost analysis of local parboiling processes. J. Food Eng. 2006, 76, 646-655.

36. Roberts, R.L.; Potter, A.L.; Kester, E.B.; Keneaster, K.K. Effect of processing conditions on the expand volume, color and soluble starch of parboiled rice. Cereal Chem. 1954, 31, 121-129.

37 Jayanarayanan, E.K. Influence of processing conditions on the browning of parboiled rice. Rice $J$. 1965, 68, 16-17.

38. Kurien P.P.; Murty, R.R.; Desikachar, H.S.R.; Subrahmanyan, V. Effect of parboiling on the swelling quality of rice. Cereal Chem. 1964, 41, 16-22.

39. Bhattacharya, K.R.; Rao, S.P.V. Processing conditions and milling yield in parboiling of rice. J. Agric. Food Chem. 1966, 14, 473-475.

40. Bhattacharya, K.R.; Rao, S.P.V. Effect of processing conditions on quality of parboiled rice. J. Agric. Food Chem. 1966, 14, 476-479. 
41. Rao, R.S.N.R.; Juliano, B.O. Effect of parboiling on some physicochemical properties of rice. J. Agric. Food Chem. 1970, 18, 289-294.

42. Gariboldi, F. Rice Parboiling; FAO Agricultural Development Paper No. 97; Food and Agriculture Organization of the United Nations: Rome, Italy, 1974.

43. Kimura, T. Effects of processing conditions on the hardening characteristics of parboiled grain. J. Soc. Agric. Struc. Jpn. 1991, 22, 49-54.

44. Kimura, T.; Bhattacharya, K.R.; Ali, S.Z. Discoloration characteristics of rice during rarboiling (I): Effect of processing conditions on the color intensity of parboiled rice. J. Soc. Agric. Struc. Jpn. 1993, 24, 23-30.

45. Kimura, T.; Shimizu, N.; Shimohara, T.; Warashina, J. Trials of quality evaluation for parboiled and other rice by means of the near infrared spectroscopy and the rapid visco analyzer. J. Soc. Agric. Struc. Jpn. 1995, 25, 175-181.

46. Unnikrishnan, K.R.; Bhattacharya, K.R. Changes in properties of parboiled rice during aging. J. Food Sci. Technol. 1995, 32, 17-21.

47. Kimura, T. Text for Group Training Course in Post-Harvest Rice Processing. Fiscal 1995, JICA: Tsukuba-shi, Ibaraki-ken, Japan, 1994.

48. Sridhar, B.S.; Manohar, B. Hydration kinetics and energy analysis of parboiling Indica paddy. Biosys. Eng. 2003, 85, 173-183.

49. Roy, P.; Shimizu, N.; Kimura, T. Energy conservation in cooking of milled raw and parboiled rice. Food Sci. Technol. Res. 2004, 10, 111-116.

50. Roy, P.; Shimizu, N.; Kimura, T. Life cycle inventory analysis of rice produced by local processes. J. Jpn. Soc. Agric. Mach. 2005, 67, 61-67.

51. Roy, P.; Shimizu, N.; Okadome, H.; Shiina, T.; Kimura, T. Life cycle of rice: Challenges and choices for Bangladesh. J. Food Eng. 2007, 79, 1250-1255.

52. Ali, N.; Pandya, A.C. Basic concept of parboiling of paddy. J. Agric. Eng. Res. 1974, 19, 111-115.

53. Islam, R.; Roy, P.; Shimizu, N.; Kimura, T. Effect of processing conditions on the physical properties of parboiled rice. Food Sci. Technol. Res. 2002, 8, 106-112.

54. Roy, P.; Shimizu, N.; Kimura, T. Effect of temperature distribution on the quality of parboiled rice produced by traditional parboiling process. Food Sci. Technol. Res. 2004, 10, 254-260.

55. Mecham, D.K.; Kester, E.D.; Pence, W.J.; Parboiling characteristics of California medium-grain rice. Food Technol. 1961, 15, 475-479.

56. Bhattacharya, K.R.; Swamy, Y.M.I. Conditions of drying parboiled paddy for optimum milling quality. Cereal Chem. 1967, 44, 592-600.

57. Soponronnarit, S.; Nathakaranakule, A.; Jirajindalert, A.; Taechapairoj, C. Parboiling brown rice using super heated steam fluidization technique. J. Food Eng. 2005, 75, 423-432.

58. Lamberts, L.; Bie, L.D.; Vandeputte, G.E.; Veraverbeke, W.S.; Derycke, V.; Man, W.D.; Delcour, J.A. Effect of milling on colour and nutritional properties of rice. Food Chem. 2007, 100, 1496-1503.

59. Sakurai, H. Study on Husking Characteristics of Impeller Type Paddy Husker (Husking Mechanism). In Proceedings of the 61st Japanese Society of Agricultural Machinery Annual Meeting, Iwate, Japan, 17-19 September 2002. 
60. Shitanda, D.; Nishiyama, Y.; Koide, S. Performance analysis of an impeller husker considering the physical and mechanical properties of paddy rice. J. Agric. Eng. Res. 2001, 79, 195-203.

61. International Rice Research Institute (IRRI). Main Milling Practices; International Rice Research Institute (IRRI): Manila, Philippines, 2003. Available online: http://www.knowledgebank. irri.org/troprice/Main-Milling-Practices.htm (accessed on 12 November 2003).

62. FAO. International year of rice. Proceedings of International Year of Rice: Twenty fourth FAO Regional Conference for Europe, Montpellier, France, 5-7 May 2004.

63. Mohapatra, D.; Bal, S. Effect of degree of milling on specific energy consumption, optical measurements and cooking quality of rice. J. Food Eng. 2007, 80, 119-125.

64. Siebenmorgen, T.J.; Qin, G. Relating rice kernel breaking force distributions to milling quality. Trans. ASAE 2005, 48, 223-228.

65. Roy, P.; Ijiri, T.; Okadome, H.; Nei, D.; Orikasa, T.; Nakamura, N.; Shiina, T. Effect of processing conditions on overall energy consumption and quality of rice. J. Food Eng. 2008, 89, 343-348.

66. Ruiten van, H.T.L. Rice Milling: An overview. In Rice Chemistry and Technology, 2nd ed.; Juliano, B.O., Ed.; American Association of Cereal Chemists: Eagan, MN, USA, 1985.

67. Juliano, B.O. The Rice Caryopsis and Its Composition. In Rice Chemistry and Technology, 1st ed.; Houston, D.F., Ed.; American Association of Cereal Chemists: Eagan, MN, USA, 1972; pp. 16-73.

68. Liang, J.; Li, Z.; Tsuji, K.; Nakano, K.; Robert, M.J.N.; Robert, H.J. Milling characteristics and distribution of phytic acid and zinc in long-, medium- and short-grain rice. J. Cereal Sci. 2008, 48, 83-91.

69. Sarker, N.N.; Miyahara, S. Breakage Characteristics and Bran Particle Distribution of Selected Rice Varieties during the Whitening Process Using Friction Roll Type Machine; Report of Special Research Project on Tropical Agricultural Resources, The University of Tsukuba: Ibaraki, Japan, 1984; Volume 3, pp. 157-168.

70. Yadav, B.K.; Jindal, V.K. Changes in head rice yield and whiteness during milling of rough rice (Oryza sativa L.). J. Food Eng. 2008, 86, 113-121.

71. Roy, P.; Ijiri, T.; Nei, D.; Orikasa, T.; Okadome, H.; Nakamura, N.; Shiina, T. Life cycle inventory (LCI) of different forms of rice consumed in households in Japan. J. Food Eng. 2009, 91, 45-55.

72. Roy, P.; Shiina, T. Rice Properties, Dietary Choices, Health and Environment. In Food Engineering; Brendan, C.S., Ed.; Nova Science Publishers: New York, NY, USA, 2011; pp. 353-403.

73. Kayahara, H.; Tsukahara, K. Flavor, Health and Nutritional Quality of Pre-Germinated Brown rice. In Proceedings of the International Chemical Congress of Pacific Basin Societies, Honolulu, HI, USA, 14-19 December 2000.

74. Saikusa, T.; Horino, T.; Mori, Y. Accumulation of gamma-aminobutyric acid (GABA) in rice germ during water soaking. Biosci. Biotechnol. Biochem. 1994, 58, 2291-2292.

75. Tian, S.; Nakamura, K.; Kayahara, H. Analysis of phenolic compounds in white rice, brown rice, and germinated brown rice. J. Agric. Food Chem. 2004, 52, 4808-4813. 
76. Hagiwara, H.; Seki, T.; Ariga, T. The effect of pregerminated brown rice intake on blood glucose and PAI-1 levels in streptozotocin-induced diabetic rats. Biosci. Biotechnol. Biochem. 2004, 68, 444-447.

77. Ito, Y.; Mizukuchi, A.; Kise, M.; Aoto, H.; Yamamoto, S.; Yoshihara, R.; Yokoyama, J. Postprandial blood glucose and insulin responses to pre-germinated brown rice in healthy subjects. J. Med. Invest. 2005, 52, 159-164.

78. Miura, D.; Ito, Y.; Mizukuchi, A.; Kise, M.; Aoto, H.; Yagasaki, K. Hypocholesterolemic action of pre-germinated brown rice in hepatoma-bearing rats. Life Sci. 2006, 79, 259-264.

79. Usuki, S.; Ito, Y.; Morikawa, K.; Kise, M.; Ariga, T.; Rivner, M.; Yu, R.K. Effect of pre-germinated brown rice intake on diabetic neuropathy in streptozotocin-induced diabetic rats. Nutr. Metabol. 2007, 4, 25.

80. Jeon, T.I.; Hwang, S.G.; Lim, B.O.; Park, D.K. Extracts of phellinus linteus grown on germinated brown rice suppress liver damage induced by carbon tetrachloride in rats. Biotechnol. Lett. 2003, 25, 2093-3006.

81. Sakamoto, S.; Hayashi, T.; Hayashi, K.; Murai, F.; Hori, M.; Kimoto, K.; Murakami K. Pre-germinated brown rice could enhance maternal mental health and immunity during lactation. Eur. J. Nutr. 2007, 46, 391-396.

82. Okada, C.; Sugiashita, T.; Murakami, T.; Murai, H.; Saikusa, T.; Horino, T.; Onodera, A.; Kazimoto, T.; Takahashi, H.; Takahashi, T. Effect on improvement of the symptoms of mental disorder, at menopause or at middle age, through the diet including defatted rice germ rich in GABA. J. Jpn. Food Sci. Technol. 2000, 47, 596-603.

83. Kunze, O.R.; Choudhury, M.S.U. Moisture adsorption related to the tensile strength of rice. Cereal Chem. 1972, 49, 684-697.

84. Siebenmorgen, T.J.; Meullenet, J.F. Impact of Drying, Storage and Milling on Rice Quality and Functionality. In Rice Chemistry and Technology, 3rd ed.; Champagne, E.T., Ed.; American Association of Cereal Chemists: Eagan, MN, USA, 2004; pp. 301-328.

85. Bechtel, D.B.; Pomeranz, Y. Ultrastructure of the mature ungerminated rice (Oryza sativa) caryopsis. The caryopsis and aleurone cells. Am. J. Bot. 1977, 64, 966-973.

86. Desikachar, H.S.R.; Rao, R.S.N.; Ananthachar, T.K. Effect of degree of milling on water absorption of rice during cooking. J. Food Sci. Technol. 1965, 2, 110-112.

87. Horigane, A.K.; Takahashi, H.; Maruyama, S.; Ohtsubo, K.; Yoshida, M. Water penetration into rice grains during soaking observed by gradient echo magnetic resonance imaging. J. Cereal Sci. 2006, 44, 307-316.

88. Velupillai, L. Parboiling Rice with Microwave Energy. In Rice Science and Technology; Marshall, W.E., Wardsworth, J.I., Eds.; Marcel Dekker: New York, NY, USA, 1994; pp. 263-274.

89. Powell, E.L. Starch: Chemistry and Technology, 2nd ed.; Whistler, R.L., Paschall, E.F., Eds.; Academic Press: New York, NY, USA, 1967; p. 523.

90. Ali, S.Z.; Bhattacharya, K.R. Hydration and amylose-solubility behavior of parboiled rice. Lebensm.-Wiss. Technol. 1972, 5, 207-212.

91. Sowbhagya, C.M.; Ali, S.Z. Effect of presoaking on cooking time and texture of raw and parboiled rice. J. Food Sci. Technol. 1991, 28, 76-80. 
92. Seki, C.; Kainuma, Y. A study of rice cooking (Part 2): Soaking time as a factor controlling rice cooking. J. Home Econ. Jpn. 1982, 33, 228-234.

93. Das, T.; Subramanian, R.; Chakkaravarthi, A.; Singh, V.; Ali, S.Z.; Bordoloi, P.K. Energy conservation in domestic rice cooking. J. Food Eng. 2006, 75, 156-166.

94. Bhattacharya, K.R.; Sowbhagya, C.M. Water uptake by rice during cooking. Cereal Sci. Today 1971, 16, 420-424.

95. Mohapatra, D.; Bal, S. Cooking quality and instrumental textural attributes of cooked rice for different milling fractions. J. Food Eng. 2006, 73, 253-259.

96. Marshall, W.E. Effect of degree of milling of brown rice ad particle size of milled rice on starch gelatinization. Cereal Chem. 1992, 69, 632-636.

97. Marshall, W.E.; Normand, F.L.; Goynes, W.R. Effect of protein removal on starch gelatinization in whole grain milled rice. Cereal Chem. 1990, 67, 458-463.

98. Fan, J.; Marks, B.P.; Daniels, M.J.; Siebenmorgen, T.J. Effects of postharvest operations on the gelatinization and retrogradation properties of long-grain rice. Trans. ASAE 1999, 42, 727-731.

99. Islam R.; Shimizu, N.; Kimura, T. Effect of processing conditions on thermal properties of parboiled rice. Food Sci. Technol. Res. 2002, 8, 131-136.

100. Bao, J.; Sun, M.; Corke, H. Analysis of genotypic diversity in starch thermal and retrogradation properties in nonwaxy rice. Carbohydr. Polym. 2007, 67, 174-181.

101. Zhou, Z.; Robards, K.; Helliwell, S.; Blanchard, C. Effect of storage temperature on rice thermal properties. Food Res. Int. 2010, 43, 709-715.

102. Kato, H.; Ohta, T.; Tsugita, T.; Hosaka, Y. Effect of parboiling on texture and flavour components of cooked rice. J. Agric. Food Chem. 1983, 31, 818-823.

103. Biswas, S.K.; Juliano, B.O. Laboratory procedures and properties of parboiled rice from varieties differing in starch properties. Cereal Chem. 1988, 65, 417-423.

104. Islam, R.; Shimizu, N.; Kimura, T. Quality evaluation of parboiled rice with physical properties. Food Sci. Technol. Res. 2001, 7, 57-63.

105. Shimizu, N.; Kimura, T.; Ohtsubo, K.; Toyoshima, H. Development of rice quality evaluating technique based on physical properties of cooked rice (Part 1). J. Jpn. Soc. Agric. Mach. 1997, 59, 75-82.

106. Roy, P.; Nei, D.; Orikasa, T.; Orikasa, T.; Okadome, H.; Thammawong, M.; Nakamura, N.; Shiina, T. Cooking properties of different forms of rice coooked with an automatic induction heating system rice cooker. Asian J. Food Agro-Ind. 2010, 3, 373-388.

107. Juliano, B.O. A simplified assay for milled rice amylase. Cereal Sci. Today 1971, 16, 334.

108. Hizukuri, S.; Takeda, Y.; Maruta, N.; Juliano, B.O. Molecular structures of rice starch. Carbohydr. Res. 1989, 189, 227-235.

109. Radhika, R.K; Ali, S.Z.; Bhattacharya, K.R. The fine structure of rice-starch amylopectin and its relation to the texture of cooked rice. Carbohydr. Polym. 1993, 22, 267-275.

110. Bhattacharya, K.R. The Chemical Basis of Rice End-Use Quality. Rice is Life: Scientific Perspectives for the 21st Century. In Proceedings of the World Rice Research Conference Held in Tokyo and Tsukuba, Tsukuba, Japan, 5-7 November 2004.

111. Priestley, R.J. Studies on parboiled rice: Part 1-comparison of the characteristics of raw and parboiled rice. Food Chem. 1976, 1, 5-14. 
112. Juliano, B.O. Criteria and Test for Rice Grain Qualities. In Rice Chemistry and Technology, 2nd ed.; Juliano, B.O., Ed.; American Association of Cereal Chemists: Eagan, MN, USA, 1985; pp. 443-517.

113. Bae, M.; Watanabe, C.; Inaoka, T.; Sekiyama, M.; Sudo, N.; Bokul, M.H.; Ohtsuka, R. Arsenic in cooked rice in Bangladesh. Lancet 2002, 360, 1839-1840.

114. Juhasz, A.L.; Smith, E.; Weber, J.; Rees, M.; Rofe, A.; Kuchel, T.; Sansom, L.; Naidu, R. In vivo assessment of arsenic bioavailability in rice and its significance for human health risk assessment. Environ. Health Perspect. 2006, 114, 1826-1831.

115. Rahman, M.A.; Hasegawa, H.; Rahman, M.A.; Rahman, M.M.H.; Miah, M.A.M. Influence of cooking method on arsenic retention in cooked rice related to dietary exposure. Sci. Total Environ. 2006, 370, 51-60.

116. Sengupta, M.K.; Hossain, M.A.; Mukherjee, A.; Ahamed, S.; Das, B.; Nayak, B.; Pal, A.; Chakraborti, D. Arsenic burden of cooked rice: Traditional and modern methods. Food Chem. Toxicol. 2006, 44, 1823-1829.

117. Roychowdhury, T.; Uchino, T.; Tokunaga, H.; Ando, M. Survey of arsenic in food composites from an arsenic-affected area of West Bengal, India. Food Chem. Toxicol. 2002, 40, 1611-1621.

118. Ackerman, A.H.; Creed, P.A.; Parks, A.N.; Fricke, M.W.; Schwegel, C.A.; Creed, J.T.; Heitkemper, D.T.; Vela, N.P. Comparison of a chemical and enzymatic extraction of arsenic from rice and an assessment of the arsenic absorption from contaminated water by cooked rice. Environ. Sci. Technol. 2005, 39, 5241-5246.

119. Laparra, J.M.; Vélez, D.; Barberá, R.; Farré, R.; Montoro, R. Bioavailability of inorganic arsenic in cooked rice: Practical aspects for human risk assessments. J. Agric. Food Chem. 2005, 53, 8829-8833.

120. Devesa, V.; Vélez, D.; Montoro, R. Effect of thermal treatments on arsenic species contents in food. Food Chem. Toxicol. 2008, 46, 1-8.

121. Signes, A.K.; Mitra, K.; Burló, F.; Carbonell-Barrachina, A.A. Contribution of water and cooked rice to an estimation of dietary intake of inorganic arsenic in a rural village in West Bengal, India. Food Addit. Cont. 2008, 25, 41-50.

122. Signes, A.K.; Mitra, K.; Burló, F.; Carbonell-Barrachina, A.A. Effect of two different rice dehusking procedures on total arsenic concentration in rice. Eur. Food Res. Technol. 2008, 226, 561-567.

123. Signes, A.K.; Mitra, K.; Burló, F.; Carbonell-Barrachina, A.A. Effect of cooking method and rice type on arsenic concentration in cooked rice and the estimation of arsenic dietary intake in a rural village in West Bengal, India. Food Addit. Cont. 2008, 25, 1345-1352.

124. Torres-Escribano, S.; Leal, M.; Vélez, D.; Montoro, R. Total and inorganic arsenic concentrations in rice sold in Spain, effect of cooking and risk assessment. Environ. Sci. Technol. 2008, 42, 3867-3872.

125. Zavala, Y.J.; Duxbury, J.M. Arsenic in Rice: I. Estimating normal levels of total arsenic in rice grain. Environ. Sci. Technol. 2008, 42, 3856-3860.

126. Norton, G.J.; Islam, M.R.; Deacon, C.M.; Zhao, F.J.; Stroud, J.L.; McGrath, S.P.; Islam, S.; Jahiruddin, M.; Feldmann, J.; Price, A.H.; et al. Identification of low inorganic and total grain arsenic rice cultivars from Bangladesh. Environ. Sci. Technol. 2009, 43, 6070-6075. 
127. Roychowdhury, T. Impact of sedimentary arsenic through irrigated groundwater on soil, plant, crops and human continuum from Bengal delta: Special reference to raw and cooked rice. Food Chem. Toxicol. 2008, 46, 2856-2864.

128. Raab, A.; Baskaran, C.; eldmann, J.; Mehrag, A.A. Cooking rice in a high water to rice ratio reduces inorganic arsenic content. J. Environ. Monit. 2009, 11, 41-44.

129. Bergman, C.J.; Goffman, F.D. A Gas Chromatographic Procedure for Determining Rice Degree of Milling. In Proceedings of Rice Technical Working Group Meeting, New Orleans, LA, USA, 29 February-4 March 2004.

130. Tran, T.U.; Suzuki, K.; Okadome, H.; Homma, S.; Ohtsubo, K. Analysis of the tastes of brown rice and milled rice with different milling yields using a taste sensing system. Food Chem. 2004, 88, 557-566.

131. Champagne, E.T.; Wood, D.F.; Juliano, B.O.; Bechtel, D.B. The rice grain and its gross composition. In Rice Chemistry and Technolog, 3rd ed.; Champagne, E.T., Ed.; American Association of Cereal Chemists: Eagan, MN, USA, 2004; pp. 77-107.

132. Subrahmanyan, V.; Sreenivasan, A.; Gupta, D.H.P. Studies on quality of rice. 1. Effect of milling on the chemical composition and commercial qualities of raw and parboiled rice. Indian J. Agric. Sci. 1938, 8, 459-486.

133. Ali, S.Z.; Bhattacharya, K.R. Changes in sugars and amino acids during parboiling of rice. J. Food Biochem. 1980, 4, 169-179.

134. Pauda, A.B.; Juliano, B.O. Effect of parboiling on the thiamine, protein and fat of rice. Starch/Staerke 1974, 47, 7-13.

135. Rao, S.P.V.; Bhattacharya, K.R. Effect of parboiling on thiamine content of rice. J. Agri. Food Chem. 1966, 14, 479-482.

136. Dimopoulos, J.S.; Muller, H.G. Effect of processing conditions on protein extraction and composition and on some other physicochemical characteristics of parboiled rice. Cereal Chem. 1972, 49, 54-61.

137. Bolling, H.; El-Baya, A.W. Effect of parboiling on the physical and chemical properties of rice. Getreide Mehl Brot 1975, 29, 230-233.

138. Ocker, H.D.; Bolling, H.; El-Baya, A.W. Effect of parboiling on some vitamins and minerals of rice: Thiamine, riboflavin, calcium, magnesium, manganese and phosphorus. Riso 1976, 25, 79-82.

139. Graham, R.D.; Welch, R.M.; Bouis, H.E. Addressing micronutrient malnutrition through enhancing the nutritional quality of staple foods: Principles, perspectives and knowledge gaps. Adv. Agron. 2001, 70, 77-142.

140. McCarrison, R.; Norris, R.V. The Relationship of Rice to Beri-beri in India. In Proceedings of the World Rice Research Conference Held in Tokyo and Tsukuba, Tsukuba, Japan, 5-7 November 2004.

141. Taylor, J.; Martin, C.D.C.; Thant, U. Preliminary Inquiry into Beriberi in Burma. In Proceedings of the World Rice Research Conference Held in Tokyo and Tsukuba, Tsukuba, Japan, 5-7 November 2004.

142. Luh, B.S.; Mickus, R.R. Parboiled Rice. In Rice Utilization; Luh, B.S., Ed.; Van Nostrand Reinhold: New York, NY, USA, 1991; Volume II, pp. 51-87. 
143. Goddard, M.S.; Young, G.; Marcus, R. The effect of amylose content on insulin and glucose responses to ingested rice. Am. J. Clin. Nutr. 1984, 39, 388-392.

144. Juliano, B.O.; Goddard, M.S. Cause of varietal difference in insulinand glucose responses to ingested rice. (Formerly Qualitas Plantarum) Plant Foods for Human Nutr. 1986, 36, 35-41.

145. Miller, B.J.; Pang, E.; Bramall, L. Rice: A high or low glycemic index food? Am. J. Clin. Nutr. 1992, 56, 1034-1036.

146. Larsen, H.N.; Christensen, C.; Rasmussen, O.W.; Tetens, I.H.; Choudhury, N.H.; Thilsted, S.H.; Hermansen, K. Infuence of parboiling and physico-chemical characteristics of rice on the glycaemic index in non-insulin-dependent diabetic subjects. Eur. J. Clin. Nutr. 1996, 50, 22-27.

147. Casiraghi, M.C.; Brighenti, F.; Pellegrini, N.; Leopardi, E.; Testolin, G. Effect of processing on rice starch digestibility evaluated by in vivo and in vitro methods. J. Cereal Sci. 1993, 17, 147-156.

148. Larsen, H.N.; Rasmussen, O.W.; Rasmussen, P.H.; Alstrup, K.K.; Biswas, S.K.; Tetens, I.; Thilsted, S.H.; Hermansen, K. Glycaemic index of parboiled rice depends on the severity of processing: study in type 2 diabetic subjects. Eur. J. Clin. Nutr. 2000, 54, 380-385.

149. Hoffpauer, D.W. Enrichment and Fortification of Rice. In Rice Chemistry and Technolog, 3rd ed.; Champagne, E.T., Ed.; American Association of Cereal Chemists: Eagan, MN, USA, 2004; pp. 405-414.

150. Report on the Research Project on Life Cycle Assessment for Environmentally Sustainable Agriculture; National Institute for Agro-Environmental Sciences (NIAES): Ibaraki, Japan, 2003.

151. Breiling, M.; Hashimoto, S.; Sato, Y; Ahamer, G. Rice-related greenhouse gases in Japan, variations in scale and time and significance for the Kyoto Protocol. Paddy Water Environ. 2005, 3, 39-46.

152. Pandey, S. Farming Must Change to Feed the World. Available online: http://www.fao.org/news/ story/en/item/9962/icode (accessed on 4 February 2009).

153. Smith, P.; Martino, D.; Cai, Z.; Gwary, D.; Janzen, H.; Kumar, P.; McCarl, B.; Ogle, S.; O’Mara, F.; Rice, C.; et al. Agriculture. In Climate Change 2007: Mitigation; Contribution of Working Group III to the Fourth Assessment Report, IPCC; Metz, B., Davidson, O.R., Bosch, P.R., Dave, R., Meyer, L.A., Eds.; Cambridge University Press: Cambridge, UK and New York, NY, USA, 2007.

154. Ramalingam, N.; Raj, A.S. Studies on the soak water characteristics in various paddy parboiling methods. Bioresour. Technol. 1996, 55, 259-261.

155. FAO. Undernourishment around the world. FAO Statistical Database. 2006. Available online: http://apps.fao.org/page/collections?subset=agriculture (accessed on 4 October 2008).

156. FAO. Production. FAO Statistical Database. 2010. Available online: http://faostat.fao.org/site/ 567/default.aspx\#ancor (accessed on 27 January 2010).

(C) 2011 by the authors; licensee MDPI, Basel, Switzerland. This article is an open access article distributed under the terms and conditions of the Creative Commons Attribution license (http://creativecommons.org/licenses/by/3.0/). 